\title{
Age and growth in three populations of Dosinia exoleta (Bivalvia: Veneridae) from the Portuguese coast
}

\author{
Paula Moura • Paulo Vasconcelos • Miguel B. Gaspar
}

Received: 31 October 2012/Revised: 25 February 2013/Accepted: 4 March 2013/Published online: 20 March 2013

(C) Springer-Verlag Berlin Heidelberg and AWI 2013

\begin{abstract}
The present study aimed at estimating the age and growth in three populations of Dosinia exoleta from the Portuguese coast (Aveiro in the north, Setúbal in the southwest and Faro in the south). Two techniques were compared to ascertain the most suitable method for ageing D. exoleta. Growth marks on the shell surface and acetate peel replicas of sectioned shells were the techniques applied. Two hypotheses were tested: growth parameters present latitudinal variation along the Portuguese coast; growth parameters are influenced by the fishing exploitation. Shell surface rings proved inappropriate for ageing this species, whereas acetate peels provided realistic estimates of the von Bertalanffy growth parameters $\left(K, L_{\infty}\right.$ and $\left.t_{0}\right)$. A latitudinal gradient in growth rate was detected, with a clear southward increase in the growth coefficient $(K)$ of $D$. exoleta (Faro $>$ Setúbal and Aveiro) indicating that warmer waters in southern Portugal provide optimal conditions for the growth of this species. Fishing exploitation in northern Portugal targets larger individuals and leaves behind a younger population of smaller individuals, decreasing the asymptotic shell length $\left(L_{\infty}\right)$ of D. exoleta from Aveiro. The overall growth performance was compared among populations of D. exoleta and with other venerid species worldwide.
\end{abstract}

Communicated by Franke.

P. Moura · P. Vasconcelos · M. B. Gaspar $(\bowtie)$

Instituto Português do Mar e da Atmosfera, I.P./IPMA,

Avenida 5 de Outubro s/n, 8700-305 Olhão, Portugal

e-mail: mbgaspar@ipma.pt

P. Vasconcelos

Departamento de Biologia, Centro de Estudos do Ambiente e do

Mar (CESAM), Universidade de Aveiro, Campus de Santiago,

3810-193 Aveiro, Portugal
Keywords Dosinia exoleta $\cdot$ Age $\cdot$ Growth · Latitudinal variation $\cdot$ Fishing effects $\cdot$ Portugal

\section{Introduction}

The rayed artemis or mature dosinia (Dosinia exoleta Linnaeus, 1758) is distributed from the Norwegian and Baltic Seas, southwards to the Iberian Peninsula, into the Mediterranean, and along the western coast of Africa to Senegal and Gabon (Tebble 1966). This species burrows deeply in sand, mud and gravel bottoms, from the intertidal zone to $70 \mathrm{~m}$ depth (Poppe and Goto 1993; Macedo et al. 1999), but can be found up to $150 \mathrm{~m}$ depth (Anon 2001). In Portugal, D. exoleta is among the target species of the bivalve dredging fleet operating in the northern coast, whereas along the southwestern and southern coasts, it constitutes a by-catch species of the dredge fishery (Gaspar et al. 2007). Fishery exploitation in the northern coast started around 2007 and since then annual landings ranged between a maximum of 37.0 tons in 2007 and a minimum of 9.4 tons in 2010 (DGPA 2012). The latest statistics available on the landings of $D$. exoleta in northern Portugal (Matosinhos wholesale market) reported total landings of 15.3 tons in 2011, corresponding to an overall value for first sale of 15.3 thousand euro (DGPA 2012).

Knowledge on the age and growth of commercially exploited bivalve species is a crucial requirement for the successful management of the fishery (Gaspar et al. 2004). In bivalves, growth rings on the shell surface have been widely used to make inferences about age and growth rate (Deval 2001). Although being the most quick and economic method, in some species it is difficult to discern real seasonal growth rings from false rings caused by gonad development and spawning, diseases, extreme temperatures, storms and 
damage during dredging (Gaspar et al. 1995, 2004; Richardson 2001; Keller et al. 2002; Moura et al. 2009). These constraints have been overcome by analysing internal shell microgrowth banding patterns revealed in acetate peel replicas of sectioned shells (Jones et al. 1990; Ramón and Richardson 1992; Richardson 2001). Although being a timeconsuming method, internal growth lines visible in acetate peel replicas generally provide a reliable record of the age and growth history of individuals (Anwar et al. 1990). However, some problems in the identification of the annual ring may also occur, especially in long-lived species. In older specimens, the umbonal region is usually eroded, making impossible to identify the first growth rings (Gaspar et al. 2004). In addition, in older individuals growth becomes slower and the later growth rings are deposited very close together at the shell margin, making them hardly discernible (Deval and Oray 1998; Ezgeta-Balić et al. 2011). Furthermore, in some years clearly defined rings may not be formed (Anwar et al. 1990). In some species, age can also be estimated by counting the growth lines visible in acetate peel replicas of the umbonal region of the shell (e.g. Anwar et al. 1990; Ridgway et al. 2011; Peharda et al. 2012).

Information on the age and growth rate of $D$. exoleta is very scarce and limited to studies on population dynamics performed in Norway by Tunberg (1979). Initially, this author attempted to find annually deposited growth marks in the shells, using surface rings and acetate peels, but both ageing techniques were unsuccessful (Tunberg 1979). Later, an in situ experiment with marked individuals was performed, but results were not satisfactory due to disturbance of the studied specimens and to the weakness of the regression analysis (Tunberg 1983a). Once again, both surface rings and acetate peels were analysed; however, it was impossible to establish an acceptable correlation between the number of growth marks and individual age (Tunberg 1983a).

Taking into account the current scarcity of information, this study aimed at improving the knowledge on the age and growth of $D$. exoleta by providing data on shell banding, age and growth rate estimates for three populations from the Portuguese coast (Aveiro in the north, Setúbal in the southwest and Faro in the south). Two techniques (surface rings and acetate peels) were employed and compared in order to ascertain which is the most suitable for ageing this species. This study allowed assessing the occurrence of latitudinal variation in the growth parameters of $D$. exoleta along the Portuguese coast, as well as comparing growth parameters between fishery-exploited (Aveiro) and unexploited (Setúbal and Faro) populations of this species. Finally, the overall growth performance (OGP) was compared among populations of $D$. exoleta and with analogous information available for other venerid species worldwide.

\section{Materials and methods}

Samples of D. exoleta were collected between May and June 2010 in three areas along the Portuguese coast: Aveiro $\left(40^{\circ} 59^{\prime}-41^{\circ} 03^{\prime} \mathrm{N}\right)$ in the northern coast, Setúbal $\left(38^{\circ} 23^{\prime}-\right.$ $\left.38^{\circ} 27^{\prime} \mathrm{N}\right)$ in the southwestern coast and Faro $\left(36^{\circ} 58^{\prime}-\right.$ $36^{\circ} 59^{\prime} \mathrm{N}$ ) in the southern coast (Fig. 1). Individuals were caught by the IPMA's RV "Diplodus" operating bivalve dredges on sandy bottoms between 8 and $12 \mathrm{~m}$ depth in the southern coast, 8 and $15 \mathrm{~m}$ depth in the southwestern coast and between 15 and $30 \mathrm{~m}$ depth in the northern. Following the usual fishing procedures, the dredges were towed for $15 \mathrm{~min}$ at a constant speed of 2 knots. The dredges used were identical to those operated by the commercial fleet. In brief, the dredge weighs around $40 \mathrm{~kg}$ and consists of a rigid iron structure with a toothed lower bar $(15 \mathrm{~cm}$ tooth length with an angle of $20^{\circ}$ ). The catch is retained in a net bag $2.5 \mathrm{~m}$ long with diamond mesh size of $25 \mathrm{~mm}$ for further details on the dredge design, characteristics and dimensions, see (Gaspar et al. 2003); (Leitão et al. 2009).

In order to assess its influence on the growth of D. exoleta, data on seawater temperature along the Portuguese coast were provided by the Hydrographical Institute (IH). For this purpose were gathered data monitored during 2010 by the oceanographic buoys closest to the bivalve collecting sites (buoys of Leixões in the northern coast, Sines in the southwestern coast and Faro in the southern coast). Mean annual temperature was compared between study areas through analysis of variance (ANOVA). If ANOVA assumptions (normality of data and homogeneity of variances) were not met, the nonparametric Kruskal-Wallis test (ANOVA on ranks) was performed. Whenever significant differences were detected by ANOVA or KruskalWallis test, pairwise multiple comparisons were made using Tukey or Dunn's tests, respectively (Zar 1999). Statistical analyses were performed with the software package SigmaStat $\odot$ (version 3.5) with significance considered for $P<0.05$.

In the laboratory, a total of 50 individuals from each collecting site were measured for shell length (SL) (maximum distance along the anterior-posterior axis) to the nearest $0.1 \mathrm{~mm}$ using a digital calliper. Specimens analysed were within the following SL (ranges Aveiro $=40.4-46.8 \mathrm{~mm} \quad(42.5 \pm 1.7 \mathrm{~mm}) ; \quad$ Setúbal $=41.7-$ $52.0 \mathrm{~mm} \quad(46.7 \pm 3.1 \mathrm{~mm}) ; \quad$ Faro $=36.9-44.3 \mathrm{~mm}$ $(41.0 \pm 2.1 \mathrm{~mm}))$. Subsequently, for estimating age and growth, the rings deposited on the external surface of the shells were counted and measured with the digital calliper. In addition, the internal structure of each shell was analysed using acetate peel replicas of polished and etched sections of resin-embedded valves, following the technique previously adopted with success in other commercially exploited bivalve species from the Portuguese coast (for 


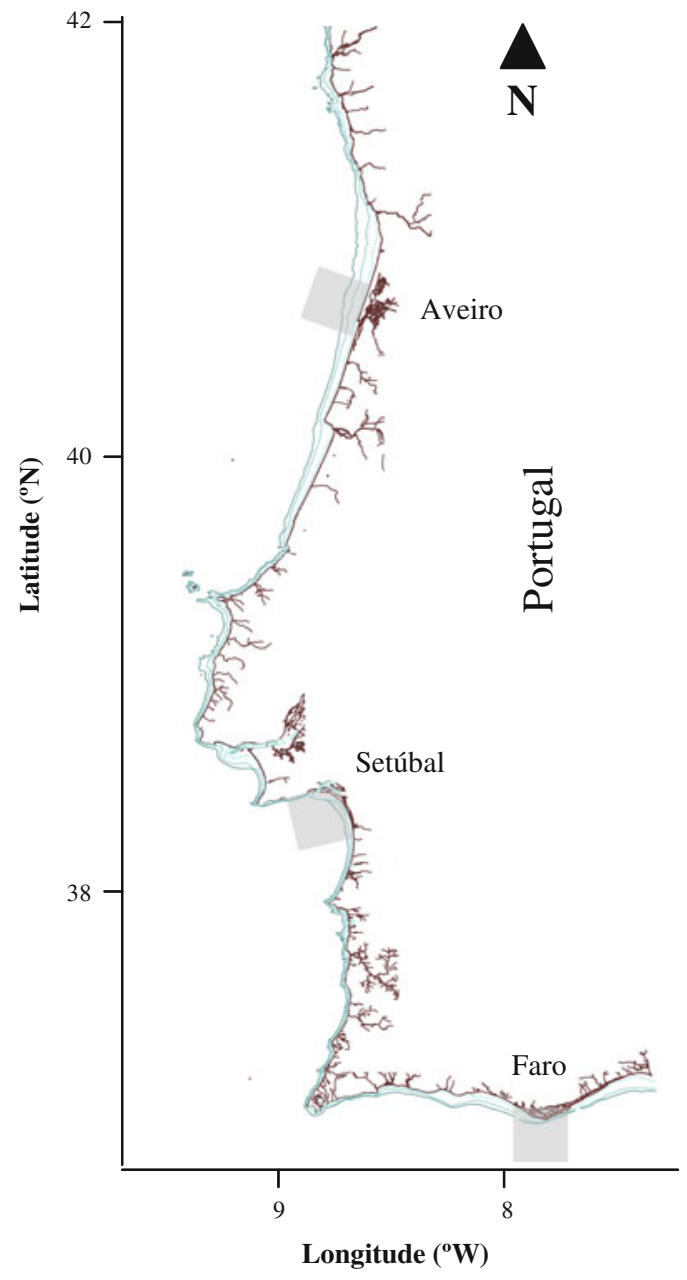

Fig. 1 Geographical location and seawater temperature at the collecting sites for Dosinia exoleta along the Portuguese coast (Aveiro, Setúbal and Faro). Shadow squares denote the collecting sites. Seawater temperature monitored during 2010 by the

further details see Gaspar et al. 1995, 2002, 2004; Moura et al. 2009). Based on previous studies with sympatric bivalve species from the Portuguese coast, such as Callista chione (Moura et al. 2009) and Chamelea gallina (Gaspar et al. 2004), it was assumed that the growth marks in the shells of $D$. exoleta are annual, being deposited in late autumn-early winter when shell growth is slower. Each growth ring observed in the acetate peel was marked on the glass slide. After digitising the entire acetate peel and respective marks, the distance between the umbo and each growth ring was measured to the nearest $0.1 \mathrm{~mm}$ using the digital image analysis software ImageJ (version 1.43). In both techniques (shell surface and acetate peels), counting and measuring of growth rings were made by two independent observers and a second reading was performed whenever numbers did not coincide. Since the measurements in acetate peels are relative to shell height $(\mathrm{SH})$, data
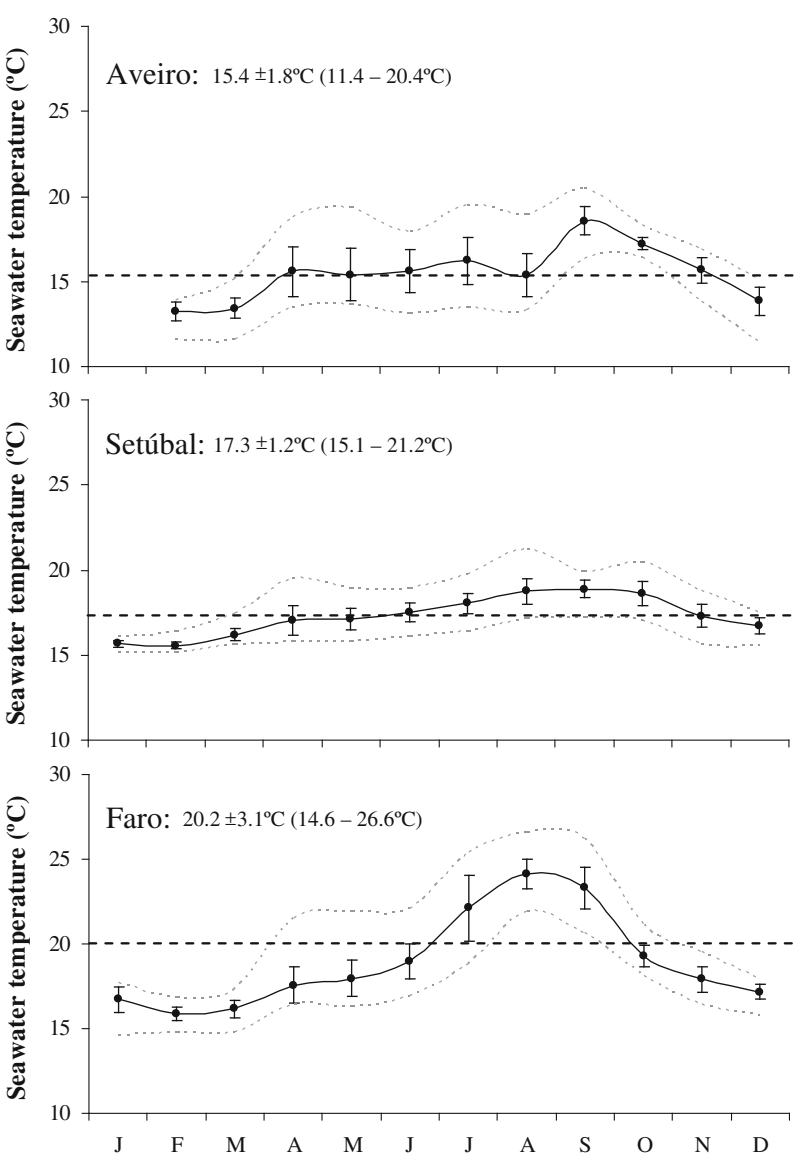

oceanographic buoys closest to the collecting sites. Error bars represent monthly standard deviation, and interrupted lines represent annual mean and range (minimum-maximum) in seawater temperature

were converted into SL using the following morphometric relationship ( $n=259, r=0.990$; Gaspar et al. 2002):

$\log \mathrm{SH}=-0.040+1.012 \log \mathrm{SL}$

Von Bertalanffy growth functions (VBGF) were fitted separately to the age-length data obtained using the two ageing methods (shell surface rings and internal growth marks). An iterative curve fitting procedure employing nonlinear least-squares regression (Gauss-Newton method) provides estimates of the growth coefficient $(K)$, asymptotic SL $\left(L_{\infty}\right)$ and theoretical age at SL (zero $\left(t_{0}\right)$, through the following equation (von Bertalanffy 1938):

$L_{t}=L_{\infty}\left[1-e^{-K\left(t-t_{0}\right)}\right]$

Linear methods commonly used in the statistical comparison of growth data (ANCOVA or ANOVA) 
cannot be employed on the VBGF because of its nonlinear formulation and high degree of correlation between its three parameters $\left(K, L_{\infty}\right.$ and $\left.t_{0}\right)$ (Chen et al. 1992). Comparisons of VBGF can be performed using two general approaches, either by testing individual parameters or by using likelihood ratio statistics. In the present case, D. exoleta growth equations were compared between populations (Aveiro, Setúbal and Faro) using likelihood ratio tests (Kimura 1980; Cerrato 1990). This method allows testing several hypotheses to compare two growth equations, by analysing each growth parameter separately or all growth parameters simultaneously. Fitting and comparison of VBGF were performed using the packages "nlstools" (Baty and Delignette-Muller 2011), "car" (Fox and Weisberg 2011) and "fishmethods" (Nelson 2011) of the free software R (version 2.14.1) (R Development Core Team 2011).

Individual growth is a nonlinear process that must be described by multiparameter nonlinear models (such as the VBGF), making it difficult to compare growth among different taxa in a definite and statistically proper way (Brey 1999). To overcome this difficulty, several growth performance indices have been developed. In the present study,OGP $(P)$ (Pauly 1979) was employed to compare the growth parameters estimated for D. exoleta in the present study with those available in the literature for other venerid species, using the following equation:

$P=\log \left(K \times L_{\infty}^{3}\right)$

\section{Results}

Mean annual seawater temperature (Fig. 1) was significantly different $(H=4292.159, P<0.001)$ between collecting sites: Aveiro $=15.4 \pm 1.8^{\circ} \mathrm{C} \quad\left(11.4-20.4^{\circ} \mathrm{C}\right)$, Setúbal $=17.3 \pm 1.2{ }^{\circ} \mathrm{C} \quad\left(15.1-21.2^{\circ} \mathrm{C}\right)$ and Faro $=$ $20.2 \pm 3.1{ }^{\circ} \mathrm{C}\left(14.6-26.6^{\circ} \mathrm{C}\right)$. There was a remarkable thermal range between the northernmost site (minimum of $11.4^{\circ} \mathrm{C}$ in December 2010 in Aveiro) and the southernmost site (maximum of $26.6{ }^{\circ} \mathrm{C}$ in August 2010 in Faro). As expected, seawater temperature displayed a clear northward decreasing trend: Aveiro $<$ Setúbal $(Q=30.519, P<0.05)$ and Setúbal $<$ Faro $(Q=31.826, P<0.05)$.

Shell surface rings and acetate peel replicas of D. exoleta shell sections are presented in Fig. 2. Observation of the outer prismatic layer revealed distinct growth patterns deposited parallel to the ventral edge of the shell, but defined lines were not found in the umbonal region. The growth marks formed a growth ring in the outer shell surface that was associated with a cleft, and occasionally, two clefts were associated with an annual growth ring (Fig. 2a). In the acetate peels, the gradual decrease in the growth increment zone was the key to distinguish annual growth rings from false rings (caused by stress or shell damage). The former were characterised by the progressive narrowing of growth bands (Fig. 2b), whereas the latter were characterised by the sudden interruption of the natural growth pattern. In false rings, it is also possible to observe a cleft in the shell surface, but the acetate peel does not display narrowing in the microgrowth increments (Fig. 2c).

The mean length-at-age and respective VBGF of D. exoleta populations from Aveiro, Setúbal and Faro, estimated using both ageing techniques (surface rings and acetate peels), are compiled in Table 1 . The VBG parameters obtained from surface rings (Fig. 2d) displayed unrealistically high asymptotic SL's (Aveiro: $L_{\infty}=$ $76.6 \mathrm{~mm}$; Setúbal: $L_{\infty}=65.8 \mathrm{~mm}$; Faro: $L_{\infty}=53.3 \mathrm{~mm}$ ), and therefore, this ageing method was considered inappropriate for estimating $D$. exoleta age and growth. The comparison between shell surface rings and microgrowth patterns revealed by the acetate peel replica of the same individual (Fig. 2a, d) supports this conclusion. In contrast, the VBG parameters $\left(K, L_{\infty}\right.$ and $\left.t_{0}\right)$ estimated using the acetate peels were fairly realistic (Table 1). Accordingly, VBGF based on growth marks revealed in the acetate peels of the three populations of D. exoleta from the Portuguese coast (Aveiro, Setúbal and Faro) are presented in Fig. 3.

The likelihood ratio tests for comparison of VBG parameters between populations of $D$. exoleta are compiled in Table 2 . When all VBG parameters $\left(K, L_{\infty}\right.$ and $\left.t_{0}\right)$ were analysed simultaneously $\left(\mathrm{H}_{4}: \mathrm{VBGF}\right)$, all growth curves displayed highly significant differences $(P<0.001)$ between the populations from Aveiro, Setúbal and Faro. When each VBG parameter was analysed separately, it was possible to determine which parameter $\left(K, L_{\infty}\right.$ or $\left.t_{0}\right)$ was significantly different among populations. The growth coefficient $\left(\mathrm{H}_{1}: K\right)$ was significantly higher in $D$. exoleta from Faro $\left(K=0.50\right.$ year $\left.^{-1}\right)$ than in the populations from Aveiro $\left(K=0.28\right.$ year $\left.^{-1}\right)$ and Setúbal $\left(K=0.30\right.$ year $\left.^{-1}\right)$. The asymptotic SL $\left(\mathrm{H}_{2}: L_{\infty}\right)$ was slightly higher in D. exoleta from Setúbal $\left(L_{\infty}=47.1 \mathrm{~mm}\right)$, although not statistically different from those in the populations from Faro $\left(L_{\infty}=42.9 \mathrm{~mm}\right)$ and Aveiro $\left(L_{\infty}=43.9 \mathrm{~mm}\right)$. Finally, the theoretical age at SL (zero $\left(\mathrm{H}_{3}: t_{0}\right)$, considered the VBG parameter with lower biological significance, only displayed significant differences between the populations from Faro $\left(t_{0}=-0.07\right.$ years $)$ and Aveiro $\left(t_{0}=0.27\right.$ years $)$ (Table 2). Overall, growth rates of $D$. exoleta presented a latitudinal gradient along the Portuguese coast and were directly related to mean annual seawater temperature at the collecting sites. Indeed, the growth rate was highest in the southernmost and warmest site (Faro: $K=0.50$ year $^{-1}$, temperature $=20.2^{\circ} \mathrm{C}$ ) and lowest in the northernmost and coldest site (Aveiro: $K=0.28$ year $^{-1}$, temperature $=$ $15.4{ }^{\circ} \mathrm{C}$ ), with the transitional population at an intermediate position (Setúbal: $K=0.30$ year $^{-1}$, temperature $=17.3{ }^{\circ} \mathrm{C}$ ). 

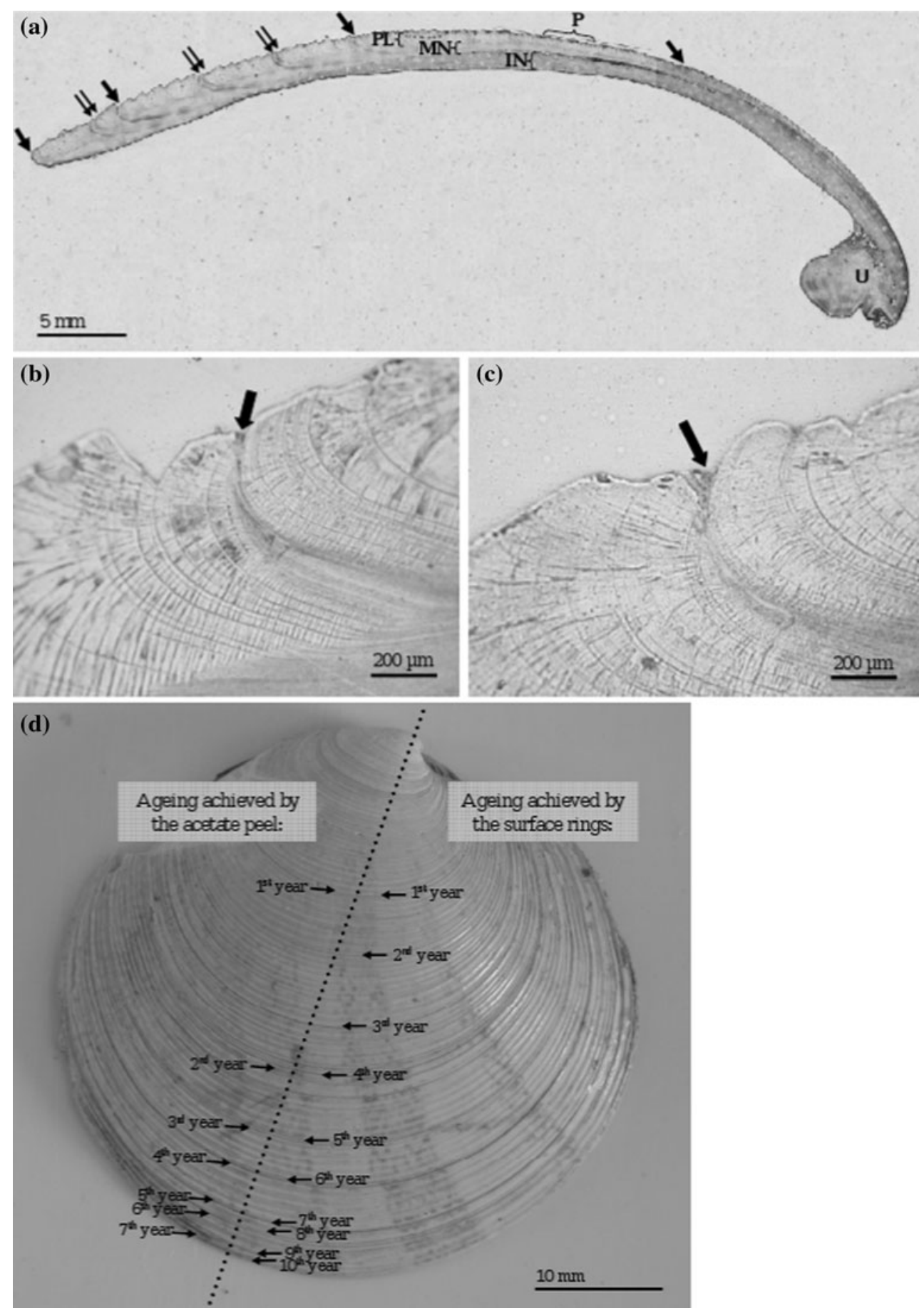

Fig. 2 Acetate peel replicas and surface growth rings in the shell of Dosinia exoleta: a Acetate peel of sectioned valve illustrating the sequential deposition of growth marks during ontogeny (from right to left). Annual growth rings are associated with one (single arrow) or two (double arrows) clefts on the shell surface. b Annual growth mark with the formation of one cleft (arrow), being possible to

Two VBG parameters ( $K$ and $L_{\infty}$ ) were applied to calculate the OGP of $D$. exoleta along the Portuguese coast. The OGP values obtained for the three studied populations were $P=4.374$ in Aveiro, $P=4.496$ in Setúbal and observe a slow-growth band where microgrowth increments become narrow. c False growth ring (arrow) without narrowing of microgrowth increments. d Comparison between growth rings observed on the shell surface and growth marks revealed by the acetate peel replica of the same shell (a). $P L$ outer prismatic layer, $M N$ middle nacreous layer, $I N$ inner nacreous layer, $P$ periostracum, $U$ umbo

$P=4.597$ in Faro. The VBG parameters and corresponding OGP values for $D$. exoleta and other venerid bivalve species are compiled in Table 3 and compared among different taxa in the auximetric grid presented in Fig. 4. 
Table 1 Mean shell length-at-age (SL) and von Bertalanffy growth function (VBGF) of D. exoleta from three locations along the Portuguese coast (Aveiro, Setúbal and Faro) obtained using two ageing techniques (shell surface rings and acetate peels)

\begin{tabular}{|c|c|c|c|c|c|}
\hline \multirow[t]{2}{*}{ Location } & \multirow[t]{2}{*}{ Age (years) } & \multicolumn{2}{|l|}{ Surface rings } & \multicolumn{2}{|l|}{ Acetate peels } \\
\hline & & Number of observations & Mean SL (mm) & Number of observations & Mean SL (mm) \\
\hline \multirow[t]{11}{*}{ Aveiro $(\mathrm{N})$} & 1 & 50 & $11.2 \pm 1.5(7.5-13.5)$ & 50 & $12.7 \pm 1.6(10.7-15.4)$ \\
\hline & 2 & 50 & $16.4 \pm 1.0(14.3-18.0)$ & 50 & $21.8 \pm 1.3(19.5-23.6)$ \\
\hline & 3 & 50 & $20.7 \pm 1.4(18.1-23.4)$ & 50 & $26.1 \pm 0.9(24.8-28.1)$ \\
\hline & 4 & 50 & $24.8 \pm 1.0(22.8-26.5)$ & 50 & $30.7 \pm 1.2(28.7-32.7)$ \\
\hline & 5 & 50 & $28.3 \pm 1.2(27.0-30.7)$ & 50 & $33.5 \pm 1.3(31.5-36.6)$ \\
\hline & 6 & 50 & $33.3 \pm 1.0(31.2-34.9)$ & 50 & $36.2 \pm 0.7(34.7-37.1)$ \\
\hline & 7 & 50 & $36.6 \pm 0.8(35.2-38.0)$ & 43 & $38.5 \pm 0.9(36.8-40.2)$ \\
\hline & 8 & 48 & $39.4 \pm 0.8(37.7-40.8)$ & 18 & $40.1 \pm 1.2(38.1-41.7)$ \\
\hline & 9 & 21 & $41.3 \pm 1.0(40.0-43.0)$ & & \\
\hline & 10 & 5 & $43.7 \pm 1.3(42.8-44.6)$ & & \\
\hline & VBGF & & $\mathrm{L}_{\mathrm{t}}=76.6\left[\left(1-\mathrm{e}^{-0.08(t+0.97)}\right]\right.$ & & $\mathrm{L}_{\mathrm{t}}=43.9\left[\left(1-\mathrm{e}^{-0.28(t+0.27)}\right]\right.$ \\
\hline \multirow[t]{12}{*}{ Setubal (SW) } & 1 & 50 & $9.5 \pm 1.0(8.1-11.4)$ & 50 & $13.2 \pm 1.1(11.5-15.6)$ \\
\hline & 2 & 50 & $14.4 \pm 1.4(12.1-17.1)$ & 50 & $19.8 \pm 2.8(14.3-23.5)$ \\
\hline & 3 & 50 & $19.5 \pm 1.4(17.4-22.1)$ & 50 & $27.6 \pm 2.7(23.0-34.1)$ \\
\hline & 4 & 50 & $23.9 \pm 1.8(20.2-26.0)$ & 50 & $33.6 \pm 3.1(28.3-40.9)$ \\
\hline & 5 & 50 & $29.1 \pm 1.5(27.2-31.6)$ & 50 & $37.1 \pm 3.6(31.1-45.4)$ \\
\hline & 6 & 50 & $33.3 \pm 1.4(31.0-35.1)$ & 46 & $39.2 \pm 2.8(34.1-44.3)$ \\
\hline & 7 & 50 & $36.4 \pm 1.3(34.2-37.9)$ & 29 & $40.1 \pm 2.7(36.0-43.0)$ \\
\hline & 8 & 47 & $38.9 \pm 1.4(36.4-41.2)$ & 25 & $42.3 \pm 3.1(37.5-45.8)$ \\
\hline & 9 & 43 & $41.4 \pm 1.2(38.1-43.0)$ & 11 & $44.4 \pm 4.9(38.8-47.4)$ \\
\hline & 10 & 30 & $43.9 \pm 0.5(43.1-44.5)$ & & \\
\hline & 11 & 13 & $46.1 \pm 1.2(44.6-47.3)$ & & \\
\hline & VBGF & & $\mathrm{L}_{\mathrm{t}}=65.8\left[\left(1-\mathrm{e}^{-0.11(t+0.37)}\right]\right.$ & & $\mathrm{L}_{\mathrm{t}}=47.1\left[\left(1-\mathrm{e}^{-0.30(t+0.2)}\right]\right.$ \\
\hline \multirow[t]{7}{*}{ Faro $(\mathrm{S})$} & 1 & 50 & $13.8 \pm 1.8(10.5-17.7)$ & 50 & $16.0 \pm 2.4(12.2-19.3)$ \\
\hline & 2 & 50 & $20.4 \pm 2.9(15.6-28.0)$ & 50 & $26.6 \pm 2.6(22.4-29.9)$ \\
\hline & 3 & 50 & $27.9 \pm 3.5(23.6-34.9)$ & 50 & $33.1 \pm 1.7(30.0-35.8)$ \\
\hline & 4 & 50 & $34.4 \pm 2.9(29.8-38.9)$ & 45 & $36.9 \pm 1.4(35.0-39.0)$ \\
\hline & 5 & 40 & $37.9 \pm 2.6(33.7-42.0)$ & 17 & $39.2 \pm 0.9(38.1-40.9)$ \\
\hline & 6 & 27 & $39.5 \pm 3.0(35.1-43.2)$ & 1 & $41.2 \pm 0.0(41.2-41.2)$ \\
\hline & VBGF & & $\mathrm{L}_{\mathrm{t}}=53.3\left[\left(1-\mathrm{e}^{-0.23(t+0.23)}\right]\right.$ & & $\mathrm{L}_{\mathrm{t}}=42.9\left[\left(1-\mathrm{e}^{-0.50(t-0.07)}\right]\right.$ \\
\hline
\end{tabular}

Data presented as mean $\pm \mathrm{SD}$ and size range

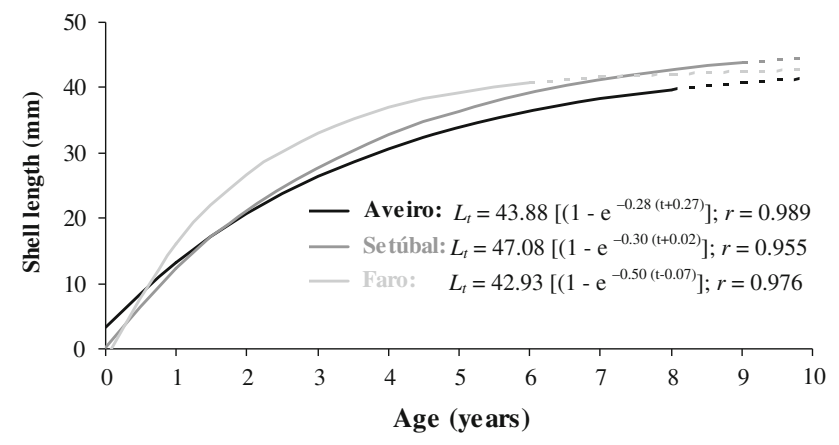

Fig. 3 Von Bertalanffy growth functions (VBGF) for the three populations of $D$. exoleta from the Portuguese coast (Aveiro, Setúbal and Faro), based on growth marks revealed in the acetate peels

\section{Discussion}

Age and growth of $D$. exoleta were more accurately estimated based on internal growth marks revealed in acetate peel replicas of sectioned shells than directly from surface growth rings. Although quick and economic, the examination of surface rings proved to be inadequate and unreliable for ageing $D$. exoleta. The unrealistic VBG parameters obtained from surface rings were already expected, because the growth rate is slower in older individuals making it difficult to distinguish and measure surface rings closer to the edge of the shell (Deval 2001; Gaspar et al. 2004; Moura et al. 2009). Differences 
Table 2 Likelihood ratio tests for comparing the von Bertalanffy growth parameters of three populations of Dosinia exoleta from the Portuguese coast (Aveiro, Setúbal and Faro)

\begin{tabular}{lllll}
\hline Locations & $\mathrm{H}_{1}: K$ & $\mathrm{H}_{2}: L_{\infty}$ & $\mathrm{H}_{3}: t_{0}$ & $\mathrm{H}_{4}:$ VBGF \\
\hline Aveiro versus. Setúbal & $\chi^{2}=0.12$ & $\chi^{2}=2.11$ & $\chi^{2}=1.99$ & $\chi^{2}=39.77$ \\
& $P=0.729$ ns & $P=0.146^{\text {ns }}$ & $P=0.158^{\text {ns }}$ & $P<0.001$ \\
Aveiro versus. Faro & $\chi^{2}=18.97$ & $\chi^{2}=0.37$ & $\chi^{2}=7.05$ & $\chi^{2}=198.91$ \\
& $P<0.001$ & $P=0.543^{\text {ns }}$ & $P=0.008^{* *}$ & $P<0.001$ \\
Setúbal versus. Faro & $\chi^{2}=6.52$ & $\chi^{2}=2.47$ & $\chi^{2}=0.23$ & $P=0.632^{\text {ns }}$ \\
& $P=0.011^{\text {ns }}$ & $P=0.116^{\text {ns }}$ & $P=0.90$ \\
\hline
\end{tabular}

$n s$ not significant

$* P<0.05 ; * * P<0.01$

between surface and internal growth rings were also observed in Macoma balthica. In this case, the number of annual lines obtained from external rings was always higher compared to the internal rings determined from the acetate peel replicas (Cardoso et al. 2012).

Examination of acetate peel replicas of $D$. exoleta allowed identifying different phases of shell growth, namely narrow dark lines (slow growth) separated by wider microgrowth increments (rapid growth). Other bivalve species from the Portuguese coast showed the same growth pattern, which has been associated with annual shell growth, including Donax trunculus (Gaspar et al. 1999), C. gallina (Gaspar et al. 2004) and C. chione (Moura et al. 2009). Periods of shell slow growth might be caused by low metabolic rates related to low seawater temperature (Lomovasky et al. 2002), lack of food (Arneri et al. 1998) and/or by diversion of metabolic products into gamete production (Lomovasky et al. 2002). Narrow bands corresponding to shell slow growth are often followed by a reduction in the peripheral layer of the shell, thus forming a cleft (Leontarakis and Richardson 2005). Indeed, in D. exoleta the narrowing of microgrowth bands also appeared to always match with a cleft on the shell surface. Moreover, occasionally two narrow bands were deposited very close together (appearing like a double band) and were reflected by the occurrence of two clefts on the shell surface. This phenomenon has also been detected in C. gallina by Ramón and Richardson (1992) and Gaspar et al. (2004). The occurrence of double clefts on the shell surface further strengthens the acetate peel technique as the most adequate and accurate method for ageing $D$. exoleta. The examination of acetate peel replicas of sectioned shells also allowed detecting several clefts associated with a sudden interruption of the natural growth pattern and that were interpreted as false rings. On the shell surface, false rings induced by gonad development and spawning, diseases, extreme temperatures, storms, predation or dredging are in most cases indistinguishable from seasonal growth rings (Gaspar et al. 2004). In some bivalve species, age can be estimated by counting the number of growth rings deposited in the umbonal region of the shell (e.g. Anwar et al. 1990; Ridgway et al. 2011; Cardoso et al. 2012; Peharda et al. 2012). However, this was unfeasible with $D$. exoleta, since in most acetate peels the growth rings in the umbonal region were absent or very difficult to discern. Similarly, in C. gallina, the growth bands in the umbonal region were only observed in a limited number of individuals, making this method inappropriate for ageing this species (Dalgiç et al. 2010).

The VBGF of the population of $D$. exoleta from Setúbal displayed the highest shell asymptotic length $\left(L_{\infty}\right)$, followed by the population from Aveiro. The population from Faro presented the lowest $L_{\infty}$, but in contrast, showed the highest growth rate $(K)$. The populations from Setúbal and Aveiro showed lower and similar growth rates $(K)$. These different growth features between populations of $D$. exoleta are probably a consequence of the fishing exploitation and certainly also reflect different environmental conditions between the collecting sites, namely in terms of seawater temperature.

Along the Portuguese coast, only the population of D. exoleta from Aveiro is exploited, whereas in Setúbal and Faro, it constitutes a by-catch species of the dredge fishery (sorted on-board and discarded alive in the fishing beds). Therefore, the fishery targeting $D$. exoleta in Aveiro certainly causes a decline in the proportion of larger individuals (decreasing $L_{\infty}$ ). Studies on the fishing impact on bivalve growth were relatively scarce but have increased recently. For instance, fishery exploitation appears to have decreased $L_{\infty}$ and $L_{\max }$ of Anadara tuberculosa from Bahía Magdalena, Mexico (Félix-Pico et al. 2009). Similarly, the decline in the abundance and sizes of A. tuberculosa over the years in Costa Rica suggest that the fishing pressure on this species is too high (Campos et al. 1990; Silva-Benavides and Bonilla-Carrion 2001).

The rayed artemis (or mature dosinia) is distributed along a widespread latitudinal range, from northern European coasts (probable northern limit in Finnmark) 
Table 3 Comparison of the von Bertalanffy growth parameters and corresponding overall growth performance between Dosinia exoleta and other venerid species worldwide

\begin{tabular}{|c|c|c|c|c|c|c|}
\hline Species & $K\left(\right.$ year $\left.^{-1}\right)$ & $L_{\infty}(\mathrm{mm})$ & $P$ & $\begin{array}{l}\text { Ageing } \\
\text { method }\end{array}$ & Study area & Reference \\
\hline D. exoleta $(\times, 1)$ & 0.28 & 43.88 & 4.374 & $\mathrm{AP}$ & Aveiro, Portugal (Atlantic Ocean) & Present study \\
\hline D.exoleta $(\times, 2)$ & 0.30 & 47.08 & 4.496 & AP & Setúbal, Portugal (Atlantic Ocean) & Present study \\
\hline D. exoleta $(\times, 3)$ & 0.50 & 42.93 & 4.597 & AP & Faro, Portugal (Atlantic Ocean) & Present study \\
\hline D. exoleta $(\times, 4)$ & 0.36 & 51.3 & 4.687 & MR & Eggholmane, Norway (Atlantic Ocean) & Tunberg (1983a) \\
\hline D. lupinus $(\times, 5)$ & 0.36 & 36.0 & 4.225 & SR & Eggholmane, Norway (Atlantic Ocean) & Tunberg (1983b) \\
\hline D. nipponica $(\times, 6)$ & 0.159 & 78.95 & 4.893 & AP & Wakkanai Port, Japan (Pacific Ocean) & Tanabe and Oba (1988) \\
\hline D. nipponica $(\times, 7)$ & 0.203 & 74.46 & 4.923 & AP & Hakodate Bay, Japan (Pacific Ocean) & Tanabe and Oba (1988) \\
\hline D. nipponica $(\times, 8)$ & 0.262 & 61.06 & 4.776 & $\mathrm{AP}$ & Tokyo Bay, Japan (Pacific Ocean) & Tanabe and Oba (1988) \\
\hline D. nipponica $(\times, 9)$ & 0.295 & 55.46 & 4.702 & AP & Seto Inland Sea, Japan (Pacific Ocean) & Tanabe and Oba (1988) \\
\hline D. nipponica $(\times, 10)$ & 0.403 & 76.44 & 5.255 & $\mathrm{AP}$ & Ariake Bay, Japan (Pacific Ocean) & Tanabe and Oba (1988) \\
\hline A. antiqua $(\bullet, 11)$ & 0.183 & 80.00 & 4.972 & MR & Chiloé, Chile (Pacific Ocean) & Clasing et al. (1994) \\
\hline A. umbonella $(\bigcirc, 12)$ & 0.28 & 58.0 & 4.737 & $\mathrm{LF}$ & Park-e-Dolat, Iran (Persian Gulf) & Saeedi et al. (2010) \\
\hline A. umbonella $(\bigcirc, 13)$ & 0.29 & 62.0 & 4.840 & $\mathrm{LF}$ & Park-e-Qadir, Iran (Persian Gulf) & Saeedi et al. (2010) \\
\hline $\begin{array}{l}\text { C. brevisiphonata } \\
(\mathbf{\square}, 14)\end{array}$ & 0.202 & 101.8 & 5.329 & SR, CS & Ussuri Bay, Russia (Sea of Japan) & Selin and Selina (1988) \\
\hline $\begin{array}{l}\text { C. brevisiphonata } \\
(\mathbf{\square}, 15)\end{array}$ & 0.177 & 102.2 & 5.276 & SR, CS & Putyatin Islands, Russia (Sea of Japan) & Selin and Selina (1988) \\
\hline $\begin{array}{l}\text { C. brevisiphonata } \\
(\mathbf{\square}, 16)\end{array}$ & 0.147 & 113.4 & 5.331 & SR, CS & Vostok Bay, Russia (Sea of Japan) & Selin and Selina (1988) \\
\hline C. chione $(\mathbf{\square}, 17)$ & 0.24 & 93.0 & 5.286 & SR, TS & Gulf of Euboikos, Greece (Aegean Sea) & Metaxatos (2004) \\
\hline C. chione $(\mathbf{\square}, 18)$ & 0.24 & 62.7 & 4.772 & AP & Thassos Island, Greece (Thracian Sea) & $\begin{array}{l}\text { Leontarakis and Richardson } \\
\text { (2005) }\end{array}$ \\
\hline C. chione $(\boldsymbol{\square}, 19)$ & 0.26 & 57.8 & 4.701 & AP & Thassos Island, Greece (Thracian Sea) & $\begin{array}{l}\text { Leontarakis and Richardson } \\
\text { (2005) }\end{array}$ \\
\hline C. chione $(\mathbf{\square}, 20)$ & 0.15 & 98.1 & 5.151 & $\mathrm{AP}$ & Arrábida, Portugal (Atlantic Sea) & Moura et al. (2009) \\
\hline C. chione $(\mathbf{\square}, 21)$ & 0.18 & 91.1 & 5.134 & SR & Arrábida, Portugal (Atlantic Sea) & Moura et al. (2009) \\
\hline C. chione $(\mathbf{\square}, 22)$ & 0.25 & 72.4 & 4.977 & $\mathrm{AP}$ & Rab Island, Croatia (Adriatic Sea) & Ezgeta-Balić et al. (2011) \\
\hline C. chione $(\mathbf{\square}, 23)$ & 0.15 & 74.5 & 4.793 & AP & Pag Bay, Croatia (Adriatic Sea) & Ezgeta-Balić et al. (2011) \\
\hline C. chione $(\mathbf{\square}, 24)$ & 0.11 & 82.8 & 4.795 & $\mathrm{AP}$ & Kaštela Bay, Croatia (Adriatic Sea) & Ezgeta-Balić et al. (2011) \\
\hline C. chione $(\boldsymbol{\square}, 25)$ & 0.34 & 79.3 & 5.229 & AP & Cetina Estuary, Croatia (Adriatic Sea) & Ezgeta-Balić et al. (2011) \\
\hline C. gallina $(\square, 26)$ & 0.35 & 36.12 & 4.217 & AP & Valencia, Spain (Mediterranean Sea) & $\begin{array}{l}\text { Ramón and Richardson } \\
\text { (1992) }\end{array}$ \\
\hline C. gallina $(\square, 27)$ & 0.40 & 40.05 & 4.410 & $\mathrm{LF}$ & Valencia, Spain (Mediterranean Sea) & Ramón (1993) \\
\hline C. gallina $(\square, 28)$ & 0.21 & 52.20 & 4.475 & TS & Ancona, Italy (Adriatic Sea) & Polenta (1993) \\
\hline C. gallina $(\square, 29)$ & 0.48 & 41.60 & 4.539 & TS & Ancona, Italy (Adriatic Sea) & Arneri et al. (1995) \\
\hline C. gallina $(\square, 30)$ & 0.52 & 39.50 & 4.506 & TS & Neretva Estuary, Croatia (Adriatic Sea) & Arneri et al. (1997) \\
\hline C. gallina $(\square, 31)$ & 0.429 & 34.17 & 4.233 & SR & Turkey (Northern Marmara Sea) & Deval and Oray (1998) \\
\hline C. gallina $(\square, 32)$ & 0.37 & 33.46 & 4.142 & TS & Turkey (Northern Marmara Sea) & Deval (2001) \\
\hline C. gallina $(\square, 33)$ & 0.609 & 27.25 & 4.091 & TS & Russia (Northern Black Sea) & $\begin{array}{l}\text { Boltachova and Mazlumyan } \\
\text { (2001) }\end{array}$ \\
\hline C. gallina $(\square, 34)$ & 0.47 & 38.95 & 4.444 & AP & Faro, Portugal (Atlantic Ocean) & Gaspar et al. (2004) \\
\hline C. gallina $(\square, 35)$ & 0.32 & 42.15 & 4.380 & $\mathrm{LF}$ & Faro, Portugal (Atlantic Ocean) & Gaspar et al. (2004) \\
\hline C. gallina $(\square, 36)$ & 0.71 & 37.55 & 4.575 & SR & Faro, Portugal (Atlantic Ocean) & Gaspar et al. (2004) \\
\hline C. gallina $(\square, 37)$ & 0.16 & 26.00 & 3.449 & TS & Yakakent, Turkey (Black Sea) & Dalgiç et al. (2010) \\
\hline C. gallina $(\square, 38)$ & 0.21 & 28.88 & 3.704 & TS & Inceburun, Turkey (Black Sea) & Dalgiç et al. (2010) \\
\hline C. gallina $(\square, 39)$ & 0.22 & 26.60 & 3.617 & TS & Cide, Turkey (Black Sea) & Dalgiç et al. (2010) \\
\hline C. striatula $(\square, 40)$ & 0.23 & 32.90 & 3.913 & SR & Millport, Scotland (Atlantic Ocean) & Ursin (1963) \\
\hline C. striatula $(\square, 41)$ & 0.25 & 38.75 & 4.163 & SR & Bristol Channel, UK (Atlantic Ocean) & Warwick et al. (1978) \\
\hline
\end{tabular}


Table 3 continued

\begin{tabular}{|c|c|c|c|c|c|c|}
\hline Species & $K\left(\right.$ year $\left.^{-1}\right)$ & $L_{\infty}(\mathrm{mm})$ & $P$ & $\begin{array}{l}\text { Ageing } \\
\text { method }\end{array}$ & Study area & Reference \\
\hline E. exalbida $(\bullet, 42)$ & 0.180 & 73.98 & 4.863 & AP, IR & $\begin{array}{l}\text { Beagle Channel, Argentina (Atlantic } \\
\text { Ocean) }\end{array}$ & Lomovasky et al. (2002) \\
\hline M. mercenaria $(\diamond, 43)$ & 0.182 & 94.31 & 5.184 & SR & Southampton, UK (Atlantic Ocean) & Hibbert (1977) \\
\hline M. mercenaria $(\diamond, 44)$ & 0.312 & 71.04 & 5.049 & $\mathrm{AP}$ & Georgia, USA (Atlantic Ocean) & Walker and Tenore (1984) \\
\hline M. mercenaria $(\diamond, 45)$ & 0.260 & 89.40 & 5.269 & $\mathrm{AP}$ & Georgia, USA (Atlantic Ocean) & Walker and Tenore (1984) \\
\hline M. mercenaria $(\diamond, 46)$ & 0.340 & 65.90 & 4.988 & $\mathrm{AP}$ & Georgia, USA (Atlantic Ocean) & Walker and Tenore (1984) \\
\hline M. mercenaria $(\diamond, 47)$ & 0.21 & 73.32 & 4.918 & CS & Narragansett Bay, USA (Atlantic Ocean) & Jones et al. (1989) \\
\hline Tawera gayi $(+, 48)$ & 0.288 & 28.03 & 3.802 & $\mathrm{AP}, \mathrm{MR}$ & $\begin{array}{l}\text { Beagle Channel, Argentina (Atlantic } \\
\text { Ocean) }\end{array}$ & Lomovasky et al. (2005) \\
\hline V. corrugata $(\mathbf{\Lambda}, 49)$ & 0.31 & 49.98 & 4.588 & SR & Mira Estuary, Portugal (Atlantic Ocean) & Guerreiro and Rafael (1995) \\
\hline V. corrugata $(\boldsymbol{\Lambda}, 50)$ & 0.43 & 45.5 & 4.608 & SR & Ria de Aveiro, Portugal (Atlantic Ocean) & Maia et al. (2006) \\
\hline V. corrugata $(\boldsymbol{\Lambda}, 51)$ & 0.29 & 54.3 & 4.667 & $\mathrm{AP}$ & Ria de Aveiro, Portugal (Atlantic Ocean) & Maia et al. (2006) \\
\hline$V$. verrucosa $(\Delta, 52)$ & 0.253 & 44.9 & 4.360 & CS & Bari, Italy (Adriatic Sea) & Arneri et al. (1998) \\
\hline V. verrucosa $(\Delta, 53)$ & 0.352 & 54.1 & 4.746 & CS & Gulf of Manfredonia, Italy (Adriatic Sea) & Arneri et al. (1998) \\
\hline$V$. verrucosa $(\Delta, 54)$ & 0.298 & 54.2 & 4.676 & $\mathrm{CS}$ & Gulf of Maliakos, Greece (Aegean Sea) & Arneri et al. (1998) \\
\hline$V$. verrucosa $(\Delta, 55)$ & 0.324 & 52.1 & 4.661 & CS & Bay of Thessaloniki, Greece (Aegean Sea) & Arneri et al. (1998) \\
\hline$V$. verrucosa $(\Delta, 56)$ & 0.360 & 43.4 & 4.469 & $\mathrm{CS}$ & Alexandroupolis, Greece (Aegean Sea) & Arneri et al. (1998) \\
\hline
\end{tabular}

$K$ growth coefficient, $L_{\infty}$ asymptotic shell length, $P$ overall growth performance, $A P$ acetate peels, $M R$ mark-recapture, $S R$ surface rings, $L F$ lengthfrequency, $C S$ cross-sections, $T S$ thin sections, $I R$ isotope ratios

(Tunberg 1984) to western African coasts, not being found further south than Congo (Fischer-Piette 1968). This implies that Portugal is fairly within the middle of the latitudinal distribution of this species in the Atlantic Ocean. It is well known that physiological processes are influenced by the environmental conditions, namely temperature and food availability (e.g. Clarke 1987; Sprung 1991; Masilamoni et al. 2002), parameters that usually show an inverse trend with latitude (Barry and Carleton 2001; Jansen et al. 2007). With increasing latitude, it has been observed an increasing trend in reproductive effort, egg and larval size, whereas an opposite trend has been shown for age at first maturity, fecundity, reproductive output, growth rate and mortality (e.g. Clarke 1987; Contreras and Jaramillo 2003; Thatje et al. 2004; Ward and Hirst 2007; Petracco et al. 2010).

In the present study, it was also detected a latitudinal gradient in the growth of the three populations of $D$. exoleta, with growth rates $(K)$ showing a southward increase (Faro $>$ Setúbal $\approx$ Aveiro). Latitudinal trends in the physiological performance of marine invertebrates are commonly observed (Santos et al. 2011). Latitude has no environmental meaning by itself, being a proxy of annual solar energy input that translates mainly into average annual seawater temperature (Heilmayer et al. 2003), but also into primary production and related parameters. On a geographical scale, differences in growth rate of bivalves have been frequently associated with latitudinal gradients in seawater temperature. Examples of this phenomenon include C. chione (Hall et al. 1974), M. balthica (Beukema and Meehan 1985), Mercenaria campechiensis and Mercenaria mercenaria (Heck et al. 2002), Mya arenaria (Appeldoorn 1995), Placopecten magellanicus (MacDonald and Thompson 1988), Tivela stultorum (Hall et al. 1974) and Zygochlamys patagonica (Gutiérrez and Defeo 2003).

In the present study along the Portuguese coast, higher seawater temperatures were registered in the south, which may explain the higher growth rate displayed by the population of $D$. exoleta from Faro compared to the populations from the other two collecting sites. However, the abundance of this species in Faro is very low compared to Setúbal and Aveiro (Fig. 5) (Gaspar et al. 2010a, b, c). This north-south decreasing trend also supports that colder waters constitute a more suitable environment for this species. Indeed, although showing wide thermal range, the optimal environmental conditions for this eurythermal species appear to be shifted northwards. Tunberg (1983a) estimated a shell asymptotic length $\left(L_{\infty}\right)$ of $51.3 \mathrm{~mm}$ for D. exoleta from Eggholmen (western Norway), but this value was considered somewhat small compared to the maximum SL (reached in that area, where this species is abundant with a density of $9.9 \pm 2.9$ ind $\mathrm{m}^{-2}$ (Tunberg 1983a). Moreover, higher abundances were observed in Raunefjorden (western Norway), where D. exoleta reached an overall density of 17.1 ind $\mathrm{m}^{-2}$ (Tunberg 1984). The higher shell asymptotic length in northern (Norway: 


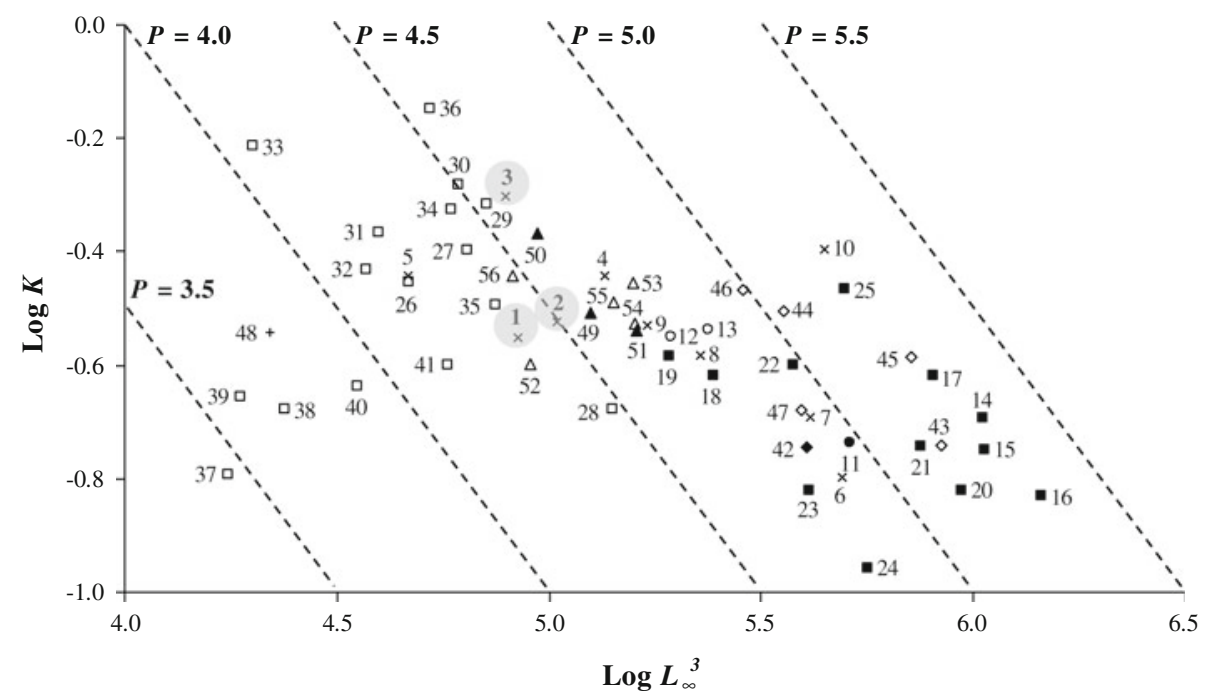

Fig. 4 Auximetric grid for comparison of OGP between D. exoleta and other venerid species worldwide. Diagonal lines denote OGP isolines, symbols and numbers refer to the species listed in Table 3 (multiplication symbol, Dosinia spp.; filled circle symbol, Ameghinomya sp.; open circle symbol, Amiantis sp.; filled square symbol,

$L_{\infty}=51.3 \mathrm{~mm}$ ) than in southern populations (Portugal: $L_{\infty}=42.9-47.1 \mathrm{~mm}$ ), further confirms that although this species grows faster in warmer waters, higher latitudes provide the most favourable environmental conditions for the development of population of $D$. exoleta.

Although with a few exceptions, the general consensus is that bivalves from low latitudes grow faster, attain a smaller maximum size and have a shorter lifespan than conspecifics from high latitudes (Newell 1964). In the present study, the calculation of the OGP allowed comparing growth among populations of $D$. exoleta and with other venerid bivalves. The values of OGP obtained for $D$. exoleta along the Portuguese coast corroborate the above-mentioned latitudinal gradient in growth and the influence of mean annual seawater temperature at the collecting sites Faro $>$ Setúbal $>$ Aveiro. In terms of intraspecific comparison, the only data available in the literature on the growth of $D$. exoleta lead to slightly higher OGP in Norway $(P=4.687)$ compared to the populations along the Portuguese coast ( $P=4.374$ in Aveiro to $P=4.597$ in Faro). In general, worldwide comparisons highlight that OGP increases with decreasing latitude, in a general trend that is correlated with average annual seawater temperature (Heilmayer et al. 2003). However, this trend was not observed in the case of D. exoleta since a higher OGP was determined for Norway compared to that obtained for the Portuguese populations. This may be a consequence of the method used by Tunberg (1983a) to estimate growth. This author applied the mark-recapture method which may lead to bias in growth estimates whenever the data set is not representative of the full size range of the population
Callista spp.; open square symbol, Chamelea spp.; filled diamond symbol, Eurhomalea sp.; open diamond symbol, Mercenaria sp.; plus symbol, Tawera sp., filled triangle symbol, Venerupis sp.; open triangle symbol, Venus sp.). Shadow circles denote $D$. exoleta populations from the Portuguese coast (Aveiro, Setúbal and Faro)

(Haddon 2001). The growth parameters estimated by Tunberg (1983a) were mainly based on large individuals, therefore are probably biased, which may have resulted in a higher OGP for the Norwegian population of D. exoleta.

Within the genus, D. exoleta both from Portugal and Norway has a slightly higher OGP than the sympatric Dosinia lupinus from western Norway $(P=4.225)$ (Tunberg 1983b), but lower than D. nipponica $(4.702<$ $P<5.255$ ) from the Pacific Ocean (Tanabe and Oba 1988). In terms of inter-specific comparison, the auximetric grid revealed that $D$. exoleta has an average growth performance (within the family Veneridae). Indeed, D. exoleta is within the range of OGP values obtained for Amiantis umbonella, Ameghinomya antiqua, Eurhomalea exalbida, Venerupis corrugata and Venus verrucosa (mainly between $4.5<P<5.0$ ). In most cases, the sympatric $C$. gallina and Chamelea striatula exhibited lower OGP (mostly $P<4.5$ ), whereas Callista brevisiphonata and $C$. chione (usually $P>5.0$ ) and $M$. mercenaria (mostly $P>5.0$ ) displayed the highest growth performances within the family Veneridae (Fig. 4).

The present study was the first to successfully estimate age and growth of $D$. exoleta by using the acetate peel technique, thus making available realistic growth parameters ( $K$ and $\left.L_{\infty}\right)$ for this species. Furthermore, the present study showed some differences between the growth parameters of the three populations. Results suggest that growth is influenced by geographical distribution and probably also by fishing exploitation. In general, the latitudinal gradient in the growth features of the three populations revealed that, besides growing faster in warm 


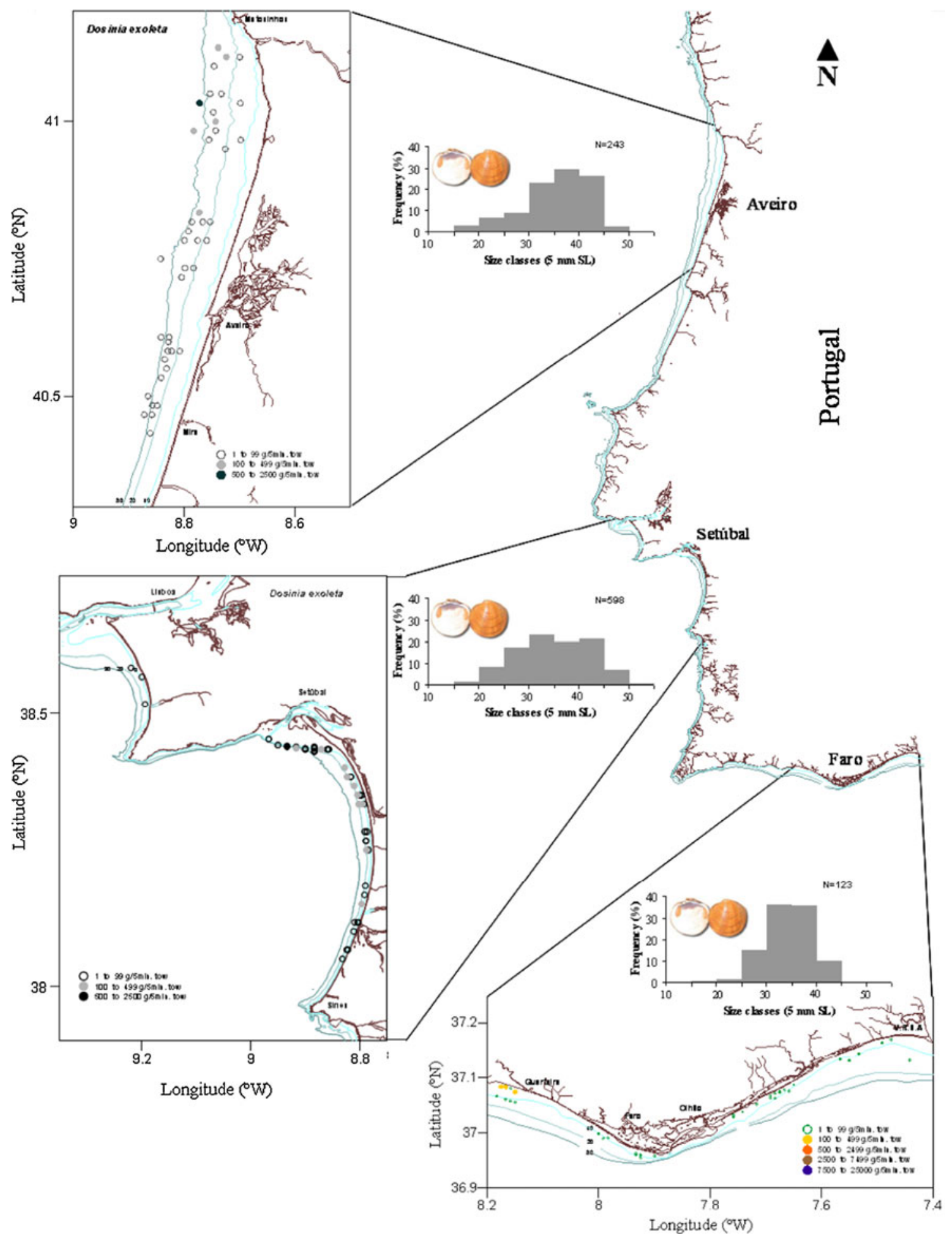

Fig. 5 Spatial distribution, abundance (g $5 \mathrm{~min}_{\text {tow }}{ }^{-1}$ ) and size frequency distribution (grouped into 5 mm shell length classes) of Dosinia exoleta from Aveiro, Setúbal and Faro during the fishing surveys performed by IPIMAR along the Portuguese coast in 2010

waters, colder environments are beneficial for this species. It also seems that fishing exploitation affects the asymptotic SL of the populations of D. exoleta (decreasing $L_{\infty}$ ), but further investigation should be performed to confirm this hypothesis. Knowledge on the age and growth of exploited bivalve species is fundamental for the proposal of 
fishery management measures. The present study provided the first data available on the growth parameters of D. exoleta, but further studies should be conducted, namely the estimation of the size at first sexual maturity, decisive for establishing a minimum landing size for the catches of this species by the bivalve dredging fleet that operates in northern Portugal.

Acknowledgments The authors would like to acknowledge the technical staff of the IPIMAR's Delegation of Aveiro for collecting and sampling the bivalves. Recognition is owed to Cte. Ventura Soares (Technical Director of the-IH) for kindly providing data on seawater temperature. Thanks are also due to João Cúrdia for photographing the acetate peel replicas of the shells. Paulo Vasconcelos is funded by a post-doctoral Grant (SFRH/BPD/26348/2006) awarded by the Fundação para a Ciência e Tecnologia (FCT-Portugal). This study was performed within the framework of the project "Desarrollo Sostenible de las Pesquerías Artesanales del Arco Atlántico-PRESPO" (Programme INTERREG IV B, co-financed by EU, ERDF funds). Finally, the authors also acknowledge two anonymous reviewers, for valuable comments and suggestions that improved the revised version of the manuscript.

\section{References}

Anon (2001) Especies de Interés Pesquero en el Litoral de Andalucía. Vol.II-Invertebrados. Junta de Andalucía, Consejería de Agricultura y Pesca, Sevilla

Anwar NA, Richardson CA, Seed R (1990) Age determination, growth rate and population structure of the horse mussel Modiolus modiolus. J Mar Biol Assoc UK 70:441-457

Appeldoorn RS (1995) Covariation in life-history parameters of softshell clams (Mya arenaria) along a latitudinal gradient. ICES Mar Sci Symp 199:19-25

Arneri E, Giannetti G, Polenta R, Antolini B (1995) Age and growth of Chamelea gallina (Bivalvia: Veneridae) in the Central Adriatic Sea obtained by thin sections. Rapp Comm Int Mer Médit 34:1-17

Arneri E, Froglia C, Polenta R, Antolini B (1997) Growth of Chamelea gallina (Bivalvia: Veneridae) in the Eastern Adriatic (Neretva River Estuary). In: Finka B (ed) Tisuću godina prvoga spomena ribarstva u Hrvata. Hrvatska akademija znanosti i umjetnosti, Zagreb, pp 669-676

Arneri E, Giannetti G, Antolini B (1998) Age determination and growth of Venus verrucosa L. (Bivalvia: Veneridae) in the southern Adriatic and Aegean Sea. Fish Res 38:193-198

Barry RG, Carleton AM (2001) Synoptic and dynamic climatology. Routledge, Boca Raton

Baty F, Delignette-Muller ML (2011) nlstools: Diagnostic tools for nonlinear regression models. $\mathrm{R}$ package version 0.0-11. http://cran.r-project.org/web/packages/nlstools

Beukema JJ, Meehan BW (1985) Latitudinal variation in linear growth and other shell characteristics of Macoma balthica. Mar Biol 90:27-33

Boltachova NA, Mazlumyan SA (2001) The linear growth and lifetime of Chamelea gallina (Bivalvia: Veneridae) in the Black Sea. Mar Ecol 55:50-52

Brey $\mathrm{T}$ (1999) Growth performance and mortality in aquatic macrobenthic invertebrates. Adv Mar Biol 35:153-223

Campos JA, Fournier ML, Soto R (1990) Estimación de la población de Anadara tuberculosa (Bivalvia: Arcidae) en Sierpe-Térraba, Costa Rica. Rev Biol Trop 38:477-480
Cardoso JFMF, Santos S, Witte JIJ, Witbaard R, van der Veer HW, Machado JP (2012) Validation of the seasonality in growth lines in the shell of Macoma balthica using stable isotopes and trace elements. J Sea Res. doi:10.1016/j.seares.2012.09.006

Cerrato RM (1990) Interpretable statistical test for growth comparison using parameters in the von Bertalanffy equation. Can J Fish Aquat Sci 47:1416-1426

Chen Y, Jackson DA, Harvey HH (1992) A comparison of von Bertalanffy and polynomial functions in modelling fish growth data. Can J Fish Aquat Sci 49:1228-1235

Clarke A (1987) Temperature, latitude and reproductive effort. Mar Ecol Prog Ser 38:89-99

Clasing E, Brey T, Stead R, Navarro J, Asencio G (1994) Population dynamics of Venus antiqua (Bivalvia: Veneracea) in the Bahia de Yaldad, Isla de Chiloé, southern Chile. J Exp Mar Biol Ecol 177:171-186

Contreras H, Jaramillo E (2003) Geographical variation in natural history of the sandy beach isopod Excirolana hirsuticauda Menzies (Cirolanidae) on the Chilean coast. Estuar Coast Shelf Sci 58S:117-126

Dalgiç G, Okumuş I, Karayücel S (2010) The effect of fishing on growth of the clam Chamelea gallina (Bivalvia: Veneridae) from the Turkish Black Sea coast. J Mar Biol Assoc UK 90:261-265

Deval MC (2001) The shell growth and the biometry of striped venus Chamelea gallina (L) in the Marmara Sea, Turkey. J Shellfish Res 20:155-159

Deval MC, Oray IK (1998) The annual shell increments of Bivalvia Chamelea gallina L. 1758 in the northern Sea of Marmara. Oebalia 24:93-109

DGPA (2012) Fishery landings database. Directorate General of Fisheries and Aquaculture (DGPA). Lisbon

Ezgeta-Balić D, Peharda M, Richardson CA, Kuzmanić M, Vrgoč N, Isajlović I (2011) Age, growth, and population structure of the smooth clam Callista chione in the eastern Adriatic Sea. Helgol Mar Res 65:457-465

Félix-Pico EF, Ramírez-Rodríguez M, Holguín-Quiñones O (2009) Growth and fisheries of the black ark Anadara tuberculosa, a bivalve mollusk, in Bahía Magdalena, Baja California Sur, Mexico. N Am J Fish Manage 29:231-236

Fischer-Piette E (1968) La distribution des Dosinia (Mollusques, Bivalves). B Mus Natl Hist Nat Paris 39:728-735

Fox J, Weisberg S (2011) An R Companion to Applied Regression, 2nd edn. Sage, Thousand Oaks CA (http://socserv.socsci.mcmas ter.ca/jfox/Books/Companion)

Gaspar MB, Castro M, Monteiro CC (1995) Age and growth rate of the clam, Spisula solida L., from a site off Vilamoura, south Portugal, determined from acetate replicas of shell sections. Sci Mar 59:87-93

Gaspar MB, Ferreira R, Monteiro CC (1999) Growth and reproductive cycle of Donax trunculus L. (Mollusca: Bivalvia) off Faro, southern Portugal. Fish Res 41:309-316

Gaspar MB, Santos MN, Vasconcelos P, Monteiro CC (2002) Shell morphometric relationships of the most common bivalve species (Mollusca: Bivalvia) of the Algarve coast (southern Portugal). Hydrobiologia 477:73-80

Gaspar MB, Leitão F, Santos MN, Chícharo L, Dias MD, Chícharo A, Monteiro CC (2003) A comparison of direct macrofaunal mortality using three types of clam dredges. ICES J Mar Sci 60:733-742

Gaspar MB, Pereira AM, Vasconcelos P, Monteiro CC (2004) Age and growth of Chamelea gallina from the Algarve coast (southern Portugal): influence of seawater temperature and gametogenic cycle on growth rate. J Mollus Stud 70:371-377

Gaspar MB, Moreno Ó, Díaz A, Manzano C (2007) La Pesca de Bivalvos en el Litoral Oceánico de la Costa Suroccidental de la Península Ibérica: Descrição da Pescaria, e Artes de Pesca, 
Medidas de Gestão, Biologia das Espécies Alvo e Catálogo de Espécies de Bivalves. Junta de Andalucía, Instituto de Investigación y Formación Agraria y Pesquera, Consejería de Agricultura y Pesca, Sevilla

Gaspar M, Moura P, Castilho F (2010a) Propostas de medidas de gestão para 2011. Relatório de Campanha, IPIMAR

Gaspar M, Moura P, Pereira F, Monteiro CC (2010b) Ponto de situação dos bancos de bivalves na zona Sul (Maio 2010). Relatório de Campanha, IPIMAR

Gaspar M, Moura P, Pereira F, Constantino R, Monteiro CC (2010c) Ponto de situação dos bancos de bivalves na zona Ocidental Sul (Maio 2010). Relatório de Campanha, IPIMAR 22 pp

Guerreiro JA, Rafael T (1995) Growth and production of Venerupis pullastra (Montagu, 1803) in the Mira Estuary (Portugal). Port Zool 3:7-13

Gutiérrez N, Defeo O (2003) Development of a new scallop Zygochlamys patagonica fishery in Uruguay: latitudinal and bathymetric patterns in biomass and population structure. Fish Res 62:21-36

Haddon M (2001) Modelling and quantitative methods in fisheries. Chapman and Hall CRC, Boca Raton

Hall CA Jr, Dollase WA, Corbató CE (1974) Shell growth in Tivela stultorum (Mawe, 1823) and Callista chione (Linnaeus, 1758) (Bivalvia): annual periodicity, latitudinal differences, and diminution with age. Palaeogeogr Palaeoclimatolol Palaeoecol 15:33-61

Heck KL, Coen LD, Wilson DM (2002) Growth of northern $[$ Mercenaria mercenaria (L.)] and southern $[$ M. campechiensis (Gmelin)] quahogs: influence of seagrasses and latitude. J Shellfish Res 21:635-642

Heilmayer O, Brey T, Chiantore M, Cattaneo-Vietti R, Arntz WE (2003) Age and productivity of the Antarctic scallop, Adamussium colbecki, in Terra Nova Bay (Ross Sea, Antarctica). J Exp Mar Biol Ecol 288:239-256

Hibbert CJ (1977) Growth and survivorship in a tidal-flat population of the bivalve Mercenaria mercenaria from Southampton water. Mar Biol 44:71-76

Jansen JM, Pronker AE, Kube S, Sokolowski A, Sola JC, Marquiegui MA, Schiedek D, Bonga SW, Wolowicz M, Hummel H (2007) Geographic and seasonal patterns and limits on the adaptive response to temperature of European Mytilus spp. and Macoma balthica populations. Oecologia 154:23-34

Jones DS, Arthur MA, Allard DJ (1989) Sclerochronological records of temperature and growth from shells of Mercenaria mercenaria from Narragansett Bay, Rhode Island. Mar Biol 102:225-234

Jones DD, Quitmyer IR, Arnold WS, Marelli DC (1990) Annual shell banding, age, and growth rate of hard clams (Mercenaria spp.) from Florida. J Shellfish Res 9:215-225

Keller N, Del Piero D, Longinelli A (2002) Isotopic composition, growth rates and biological behaviour of Chamelea gallina and Callista chione from the Gulf of Trieste (Italy). Mar Biol 140:9-15

Kimura DK (1980) Likelihood methods for the von Bertalanffy growth curve. Fish Bull 77:765-776

Leitão F, Gaspar MB, Santos MN, Monteiro CC (2009) A comparison of bycatch and discard mortality in three types of dredge used in the Portuguese Spisula solida (solid surf clam) fishery. Aquat Living Resour 22:1-10

Leontarakis PK, Richardson CA (2005) Growth of the smooth clam, Callista chione (Linnaeus, 1758) (Bivalvia: Veneridae) from the Thracian Sea, northeastern Mediterranean. J Mollus Stud 71:189-198

Lomovasky BJ, Brey T, Morriconi E, Calvo J (2002) Growth and production of the venerid bivalve Eurhomalea exalbida in Beagle Channel, Tierra del Fuego. J Sea Res 48:209-216

Lomovasky BJ, Brey T, Morriconi E (2005) Population dynamics of the venerid bivalve Tawera gayi (Hupé, 1854) in the Ushuaia Bay, Beagle Channel. J Appl Ichthyol 21:64-69
MacDonald BA, Thompson RJ (1988) Intraspecific variation in growth and reproduction in latitudinally differentiated populations of the giant scallop Placopecten magellanicus (Gmelin). Biol Bull 175:361-371

Macedo MCC, Macedo MIC, Borges JP (1999) Conchas Marinhas de Portugal (Seashells of Portugal). Editorial Verbo, Lisboa

Maia F, Sobral MP, Gaspar MB, Pimenta J (2006) Estudo do crescimento de Solen marginatus e Venerupis pullastra na Ria de Aveiro. Bases científicas para a gestão destes recursos. Relatórios Científicos e Técnicos IPIMAR, Série Digital 34:1-40

Masilamoni JG, Nandakumar K, Jesudoss KS, Azariah J, Satapathy KK, Nair KVK (2002) Influence of temperature on the physiological responses of the bivalve Brachiodontes striatulus and its significance in fouling control. Mar Environ Res 53:51-63

Metaxatos A (2004) Population dynamics of the venerid bivalve Callista chione (L.) in a coastal area of the eastern Mediterranean. J Sea Res 52:293-305

Moura P, Gaspar MB, Monteiro CC (2009) Age determination and growth rate of a Callista chione population from the southwestern coast of Portugal. Aquat Biol 5:97-106

Nelson GA (2011) fishmethods: Fisheries methods and models in R. R package version 1.2-0. http://cran.r-project.org/web/packages/ fishmethods

Newell GE (1964) Physiological variation in intertidal molluscs. In: Wilbur KM, Yonge CM (eds) Physiology of molluscs, vol I. Academic Press, New York, pp 59-87

Pauly D 1979. Gill size and temperature as governing factors in fish growth: a generalization of von Bertalanffy's growth formula. Ph.D. thesis, Berichte des Institut für Meereskunde an der Christian-Albrechts Universität zu Kiel 63:1-156

Peharda M, Ezgeta-Balić D, Radman M, Sinjkević N, Vrgoč N, Isajlović I (2012) Age, growth and population structure of Acanthocardia tuberculata (Bivalvia:Cardiidae) in the eastern Adriatic Sea. Sci Mar 76:59-66

Petracco M, Cardoso RS, Corbisier TN (2010) Population biology of Excirolana armata (Dana, 1853) (Isopoda, Cirolanidae) on an exposed sandy beach in Southeastern Brazil. Mar Ecol 31:330-340

Polenta R (1993) Osservazioni sull'acrescimento della vongola Chamelea gallina L. nel Medio Adriatico. Tezi di Laurea in Scienze Biologiche. Università degli studi di Bologna

Poppe GT, Goto Y (1993) European seashells, vol. 2 (scaphopoda, bivalvia, cephalopoda). Verlag Christa Hemmen, Wiesbaden

Ramón M (1993) Estudio de las poblaciones de Chamelea gallina (Linnaeus, 1758) y Donax trunculus (Linnaeus, 1758) (Mollusca: Bivalvia) en el Golfo de Valencia (Mediterraneo Occidental). Ph.D. thesis, Universidad de Barcelona

Ramón M, Richardson CA (1992) Age determination and shell growth of Chamelea gallina (Bivalvia: Veneridae) in the western Mediterranean. Mar Ecol Prog Ser 89:15-23

Richardson CA (2001) Molluscs as archives of environmental change. Oceanogr Mar Biol Ann Rev 39:103-164

Ridgway ID, Richardson CA, Enos E, Ungvari Z, Austad SN, Philipp EER, Csiszar A (2011) New species longevity record for the northern quahog (=Hard Clam), Mercenaria mercenaria. J Shell Res 30:35-38

Saeedi H, Ardalan AA, Kamrani E, Kiabi BH (2010) Reproduction, growth and production of Amiantis umbonella (Bivalvia: Veneridae) on northern coast of the Persian Gulf, Bandar Abbas. Iran J Mar Biol Assoc UK 90:711-718

Santos S, Cardoso JFMF, Carvalho C, Luttikhuizen PC, van der Veer HW (2011) Seasonal variability in somatic and reproductive investment of the bivalve Scrobicularia plana (da Costa, 1778) along a latitudinal gradient. Estuar Coast Shelf Sci 92:19-26

Selin NI, Selina MS (1988) Production characteristics of the bivalve mollusc Callista brevisiphonata in Peter the Great Bay, Sea of Japan. Sov J Mar Biol 14:219-223 
Silva-Benavides A-M, Bonilla-Carrion R (2001) Abundancia y morfometria de Anadara tuberculosa y A. similis (Mollusca: Bivalvia) en el Manglar de Purruja, Golfo Dulce. Costa Rica. Rev Biol Trop 49:315-320

Sprung M (1991) Costs of reproduction: a study on metabolic requirements of the gonads and fecundity of the bivalve Dreissena polymorpha. Malacologia 33:63-70

Tanabe K, Oba T (1988) Latitudinal variation in shell growth patterns of Phacosoma japonicum (Bivalvia: Veneridae) from the Japanese coast. Mar Ecol Prog Ser 47:75-82

R Development Core Team (2011) R:A language and environment for statistical computing. R Foundation for Statistical Computing, Vienna http://www.r-project.org

Tebble N (1966) British bivalve seashells. A handbook for identification. British Museum, Edinburgh

Thatje S, Lovrich GA, Anger K (2004) Egg production, hatching rates, and abbreviated larval development of Campylonotus vegans Bate, 1888 (Crustacea: Decapoda: Caridea), in subantarctic waters. J Exp Mar Biol Ecol 301:15-27

Tunberg B (1979) Dosinia exoleta (L.) (Bivalvia)—en populationsekologisk undersökning på grunt vatten i Raunefjorden, VästNorge. Cand. Real. thesis, University of Bergen

Tunberg B (1983a) Growth of Dosinia exoleta (L.) (Bivalvia) in Raunefjorden, western Norway. Sarsia 68:41-45
Tunberg B (1983b) Population structure, size distribution, and shell growth of Dosinia lupinus (L.) (Bivalvia) in Raunefjorden, western Norway, with biometrical comparison to Dosinia exoleta (L.). Sarsia 68:33-40

Tunberg B (1984) Population ecology of Dosinia exoleta (L.) (Bivalvia) in Raunefjorden, western Norway. Sarsia 69:159-168

Ursin E (1963) On the incorporation of temperature in the von Bertalanffy growth equation. Medd Danm Fisk Havunders $4: 1-16$

Von Bertalanffy L (1938) A quantitative theory of organic growth. Hum Biol 10:181-213

Walker RL, Tenore KR (1984) The distribution and production of the hard clam, Mercenaria mercenaria, in Was saw Sound, Georgia. Estuaries 7:19-27

Ward P, Hirst AG (2007) Oithona similis in a high latitude ecosystem: abundance, distribution and temperature limitation of fecundity rates in a sac spawning copepod. Mar Biol 151:1099-1110

Warwick RM, George CL, Davies JR (1978) Annual macrofauna production in a Venus community. Estuar Coast Mar Sci $7: 215-241$

Zar JH (1999) Biostatistical analysis, 4th edn. Prentice Hall, New Jersey 